\title{
Head injury of Vietnamese pedestrian in crash accident with SUV using numerical simulation
}

\author{
Hung Anh Ly ${ }^{1,2,{ }^{*}}$, Dinh Bao Nguyen ${ }^{1,2}$, Anh Huy Nguyen ${ }^{1,2}$
}

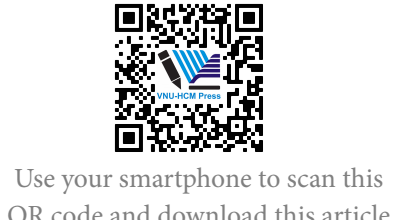

QR code and download this article

\begin{abstract}
Crash test simulation using finite-element method is more and more popular in the automobile industry because of its feasibility and cost saving. The majority of finite element dummy models used in crash simulation are built based on anthropometrical and biomechanical data of the USA and European bodies. Thus, it is necessary to develop a scaling algorithm to scale a reference dummy size into a desired one without rebuilding the entire model. In this paper, a brief review of scaling method to archive $V$-dummy is presented. V-dummy is scaled from the Hybrid III dummy model provided by LS-DYNA to suit Vietnamese anthropometry. In particular, head injury risk of a pedestrian involved in a frontal impact with a SUV is studied. Total of fifteen simulations were conducted to investigate the head injury by using HIC (Head Injury Criterion). When striking by a car, the head will hit on car bonnet first and fly in the air later before impacting to ground. The position of head impact on car strongly depends on impact angle, but landing posture on ground of pedestrian is not correlated with impact speed or angle. In the phase of car-impact, pedestrians suffer from a low level of head injury, whereas in the ground-impact, HIC exceeds the threshold of human tolerance except speed of $20 \mathrm{~km} / \mathrm{h}$. When pedestrian is hit by SUV at angle $90^{\circ}$, the shoulder strike on car bonnet before head, it causes HIC in impact angle $90^{\circ}$ is lower than $0^{\circ}$ and $45^{\circ}$. It cannot be recognized the correlation between $\mathrm{HIC}$ and impact speed in the phase of ground-impact.
\end{abstract}

Key words: Crashworthiness, pedestrian fatality, dummy, HIC, acceleration

${ }^{1}$ Falcuty of Transportation Engineering, Ho Chi Minh City University of Technology, Vietnam

${ }^{2}$ Viet Nam National University Ho Chi Minh City, Vietnam

Correspondence

Hung Anh Ly, Falcuty of Transportation Engineering, Ho Chi Minh City University of Technology, Vietnam

Viet Nam National University Ho Chi Minh City, Vietnam

Email: lyhunganh@hcmut.edu.vn

History

- Received: 16-8-2019

- Accepted: 25-3-2021

- Published: 09-4-2021

DOI : 10.32508/stdjet.v3iSI2.555

\section{Check for updates}

\section{Copyright}

(.) VNU-HCM Press. This is an openaccess article distributed under the terms of the Creative Commons Attribution 4.0 International license.

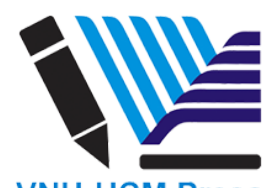

VNU-HCM Press

\section{INTRODUCTION}

Traffic accidents still occur every day, every hour, taking away the health and lives of many people. Traffic accidents not only cause consequences for victims but also lead to many other corollaries, many families have to face difficulties, debts and deadlock. The rate of road traffic fatalities per 100,000 populations in South-East Asia still higher compared to the average rate of the world in 2013 and 2016 (Figure 1) ${ }^{1}$. Traffic accidents in Vietnam in 2018 decreased slightly compared to 2017 , nationwide there were 18,232 traffic accidents causing 8,200 deaths as shown in Figure 2; 5,124 wounded people and 9,070 minor injuries as shown in Figure $3^{1}$ - General Statistics Office of Vietnam. Compared to the previous year, traffic accidents decreased in all three criteria in 2018, the number of accidents decreased by $9.2 \%$, the number of deaths decreased by $1.9 \%$; the number of injured people decreased by $8.3 \%$ and the number of minor injuries decreased by $20.8 \%$. Of the total of 9,446 traffic accidents from less serious or more, 9,202 cases (accounting for 97.4\%) occurred on the road, causing 7,958 deaths and 5,060 injuries. In 2018, there were 50 traffic accidents per day throughout the country ( 5 cases down compared to 2017), including 26 traffic accidents from less serious and more and 24 traffic collisions, making 22 people died, 14 were injured and 25 were slightly injured.

With the attempt to develop the government's transport infrastructure, the rate of deaths and injuries due to traffic accidents decreased each year.

\section{RESEARCH METHODOLOGY}

For the study of car-pedestrian crashes, it is two common methods that can be employed: conducting crash tests with mechanical dummies and simulating car crashes on computer. The former is a traditional way and gives good results compared with real life car impact; however, its disadvantage is very expensive test equipment and generally more time-consuming than the latter because after every crash test, experimental vehicles as well as dummies need repairing to be ready for the next experiments. On the other hand, with the advent of digital computers, car crash simulation using finite element method (FEM) becomes more common in car industries in these days because it opens a new modern way for engineers to run crash tests inside computers rather than on roads. In addition, not only does it save time and be less expensive 


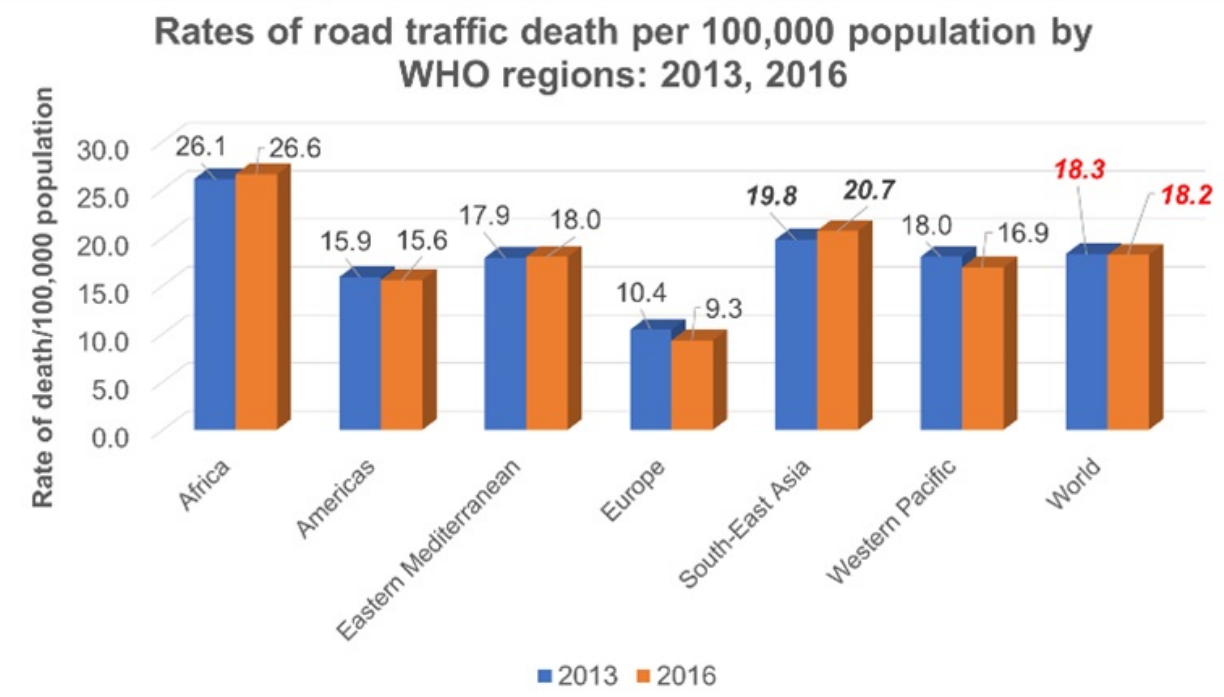

Figure 1: Rates of road traffic deaths per 100,000 populations by WHO region: $2013-2016$.

\section{Number of deaths due to traffic accidents in the 5-year} period from 2013 to 2018

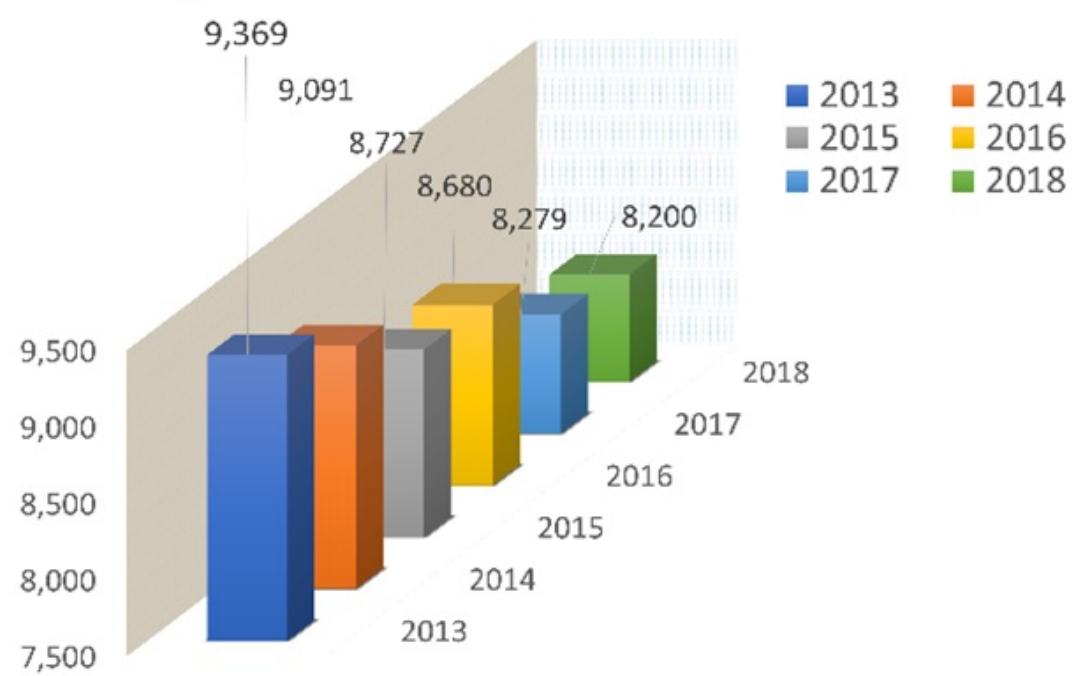

Figure 2: Number of deaths due to traffic accidents in the 5-year period. 


\section{Number of people injured due to traffic accidents in the 5-year period from 2013 to 2018}

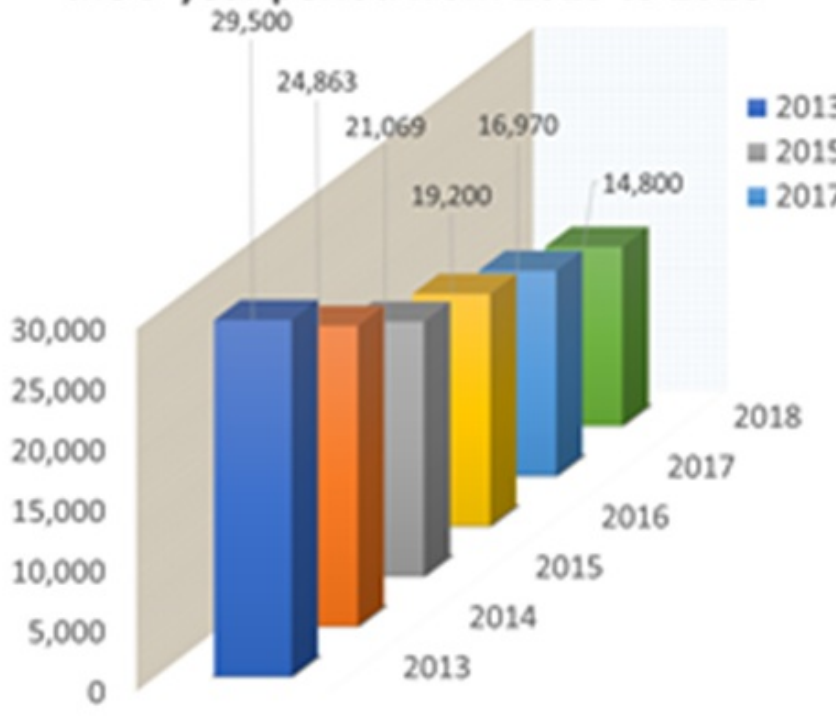

Figure 3: Number of people injured due to traffic accidents in the 5-year period.

than real crash tests, it also gives designers and engineers many chances to modify and customize designs for each parts of the car without making changes to the whole models. Consequently, more virtual crash tests run, more insights engineers can gain to fully understand their design to give the best product. As a result, car crash simulation using FEM is a promising and suitable method for the research.

For this study, LS-DYNA is chosen because of its capability to simulate highly nonlinear problems including car crashes. Hybrid III 50th dummy is popular use for human modal in kinematics analysis. Because this dummy is built based on fiftieth percentile male (equal in height and weight of the average North American), V-dummy was firstly developed in Ly et al. $(2019)^{2}$ by scaling algorithm presented in Hyncik $(2007)^{3}$, Untaroiu $(2007)^{4}$. Hybrid III $50^{\text {th }}$ dummy is transformed to a dummy model representing Vietnamese. Dummy and Vietnamese anthropometry are shown in Table 1 . The scaling algorithm comprises three steps

- Scaling of dummy geometry

- Scaling of inertial properties

- Scaling of joint properties

\section{HEAD INJURY}

Pedestrian head injuries are the main causes of pedestrian fatalities and disabilities in pedestrian to mo- tor vehicle collision ${ }^{7}$. The mechanisms and behaviors of pedestrian head in collision are unpredictable in real cases. In spite of the development of automotive safety industry, the only injury criteria in wide use is the Head Injury Criterion (HIC), which was developed in the $90 \mathrm{~s}$.

\section{Head injury criterion}

HIC was first idealized in 1961 by Gadd in his research. He also developed his criterion - Gadd severity index (GSI). After that, it was truly finalized by Versace (1971), which known as a function of average linear acceleration correlated to the Wayne State University tolerance curve. But it was first only published widely by the US National Highway Traffic Safety Administration (NHTSA) and is expressed as:

$$
H I C=\max \left[\frac{1}{t_{2}-t_{1}} \int_{t_{1}}^{t_{2}} a(t) d t\right]^{2.5}\left(t_{2}-t_{1}\right)
$$

where $t_{2}$ and $t_{1}$ : two arbitrary times during acceleration pulse. Linear acceleration a is a function of time (seconds), which measured in multiples of gravity acceleration (g's).

The average linear acceleration $\bar{a}$ of $a(t)$ between two phases $t_{2}$ and $t_{1}$ can be expressed as:

$$
\bar{a}=\frac{1}{t_{2}-t_{1}} \int_{t_{1}}^{t_{2}} a(t) d t
$$


Table 1: The table of weight and height of Hybrid III $^{5}$ and Vietnamese dummy ${ }^{6}$.

\begin{tabular}{lll}
\hline & Hybrid III & Vietnamese dummy \\
Height $(\mathrm{cm})$ & 175 & 164 \\
Mass $(\mathrm{kg})$ & 78 & 58 \\
\hline
\end{tabular}

And the head injury criterion (HIC) can be calculated as:

$$
\begin{aligned}
& H I C=\max \left(t_{1} \text { or } t_{2}\right) \times \\
& \left\{\left(t_{2}-t_{1}\right)\left[\frac{1}{t_{2}-t_{1}} \int_{t_{1}}^{t_{2}} a(t) d t\right]^{2.5}\right\}
\end{aligned}
$$

where HIC is the maximum value between the impact time $t_{2}$ and $t_{1}$ of the brackets \{\} , while the index 2.5 based on the real case accidents.

Since the HIC index had an important part in automotive safety industry, there are still some limitations on HIC as an injury severity criterion such as:

- Rotating acceleration of head is skipped.

- Only hard contacts are taken into account.

\section{Scaling of Head Injury Criterion}

Moreover, a simple method developed by Mertz et al. ${ }^{8}$ to scale HIC for various dummy sizes. For the sake of convenience, three dimensionless fundamental ratios are

Length scale ratio: $\lambda_{L}=\frac{L_{1}}{L_{2}}$

Mass density ratio: $\lambda_{m}=\frac{\rho_{1}}{\rho_{2}}$

Modulus of elasticity ratio: $\lambda_{E}=\frac{E_{1}}{E_{2}}$

where $\mathrm{L}$ is where $\mathrm{L}$ is the characteristic length, $\rho$ is density, and $\mathrm{E}$ is modulus of elasticity.

Assume that the density and modulus of elasticity remain constant for two subjects, hence $\lambda_{m}=1$ and $\lambda_{E}=1$. Therefore, a scaling factor for HIC can be written as:

$$
\lambda_{H I C} \propto \frac{1}{\left(\lambda_{L}\right)^{1.5}}
$$

This method has the pros and cons. The advantage is it is simple and straightforward to use, but because its derivation is based on the assumption that considering head impact to be represented as a singledegree-of-freedom spring-mass system, so it does not account for the complexity of a real-life impact. However, the main purpose for introducing this method here is to realize that the scale factor of HIC is inversely proportional to the length scale factor, which means the smaller in size, the greater in HIC. This fact will be used to verify results of simulations associated with the scaled dummy.

\section{A proposed method for verification of the scaled dummy}

In the scope of this study, it is difficult to verify the scaled dummy because there are no available experimental data or theoretical results associated with Vietnamese pedestrian-car crashes. Therefore, the verification of the scaled dummy is limited to evaluate qualitatively by using Eq. (4) that indicates the inverse proportion between HIC and dummy sizes. Therefore, the values of HIC of the scaled dummy are expected to be larger than those of the Hybrid III $50^{\text {th }}$ dummy.

\section{Abbreviated injury scale}

The Abbreviated Injury Scale (AIS) points out risk of fatality for a given injury level correlated to the head injury criterion (HIC). There are six injury levels from 1 (minor injuries) to 6 (fatal, non-survivable). The correlation between HIC and AIS is presented in Table 2 .

\section{RESULT VERIFICATION}

\section{The Hybrid III $50^{\text {th }}$ dummy verification}

In this section, due to the lack of available experimental data for SUV-pedestrian crashes, a simulation between the Hybrid III $50^{\text {th }}$ dummy and a sedan is done to compare experimental data ${ }^{9}$ and simulation results. Besides, the computer simulation conducted in Elmasoudi (2015) ${ }^{9}$, namely paper simulation which performed pedestrian-sedan crashes, are also added for comparison. The acceleration results from simulation are filtered following SAE CFC1000 specification. Full model is shown in Figure 4. Termination time is set to 0.25 second, and 0.6 is chosen to compute stable time step between iterations. Two main types of contact used are automatic single surface for handling self-contact, and automatic surfaceto-surface for general contact. In terms of boundary conditions, automatic single surface is used for the whole car model, and automatic surface-to-surface is applied for contacts between the dummy and the car, four car tires and the ground, and the dummy and the ground. In this verification of the Hybrid III $50^{\text {th }}$ dummy, the car's velocity is $40 \mathrm{~km} / \mathrm{h}$, and both of the dummy and the car are subjected to gravity. 


\begin{tabular}{lll}
\hline Table 2: The correlation between Head Injury Criterion and Abbreviated Injury Scale ${ }^{6}$ \\
\hline HIC & AIS & $\begin{array}{l}\text { Level of head injury - brain concussion } \\
\text { Headache or dizziness; light brain or cervical injuries }\end{array}$ \\
$520-519$ & 1 & $\begin{array}{l}\text { Concussion with or without skull fracture; less than } 15 \text { mins unconsciousness; } \\
\text { face/nose fracture }\end{array}$ \\
$900-1254$ & 3 & $\begin{array}{l}\text { Concussion with or without skull fracture; more than } 15 \text { mins unconsciousness, } \\
\text { but without severe neurological damages; no damages of spiral cord }\end{array}$ \\
$1255-1574$ & 4 & $\begin{array}{l}\text { Skull fracture with severe damage injuries } \\
\text { Concussion with or without skull fracture with hemorrhage and/or critical neu- } \\
1575-1859\end{array}$ \\
5 & 6 & $\begin{array}{l}\text { rological damages; unconsciousness greater than } 12 \text { hours } \\
\text { Non-survivable }\end{array}$
\end{tabular}
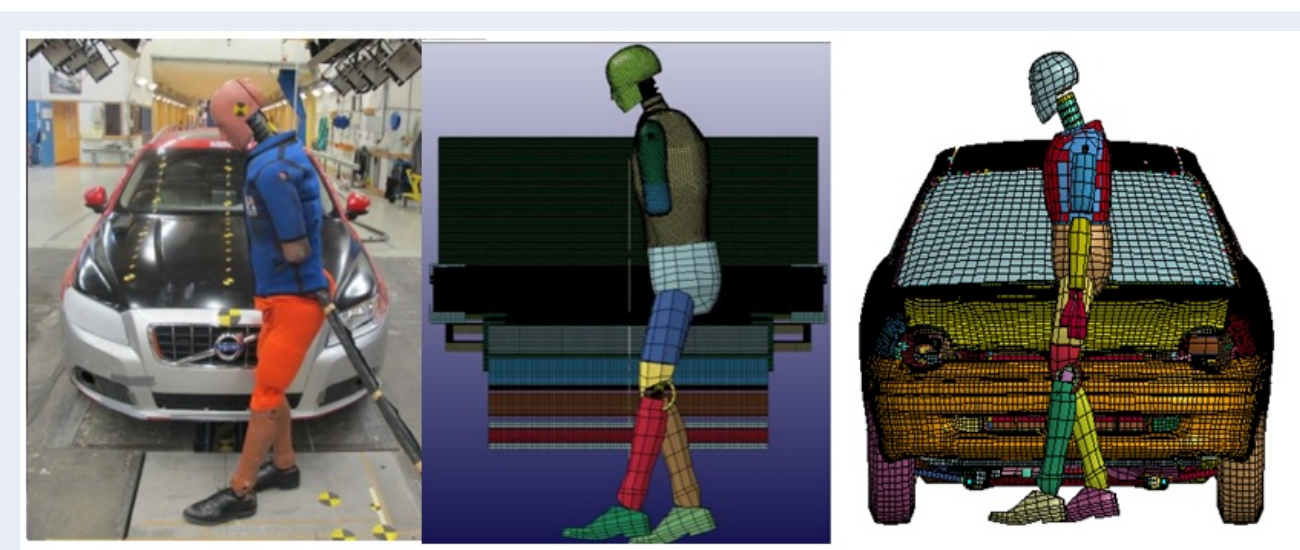

Figure 4: Full model set-up. From left to right: experimental set-up ${ }^{9}$, reference paper simulation' set-up ${ }^{9}$, this reseach's simulation.

As can be seen Figure 5, the head accelerations in the $\mathrm{x}$-direction and $\mathrm{z}$-direction in the simulation have the same waveform as those in the experiment. The contact between the dummy's head and the car hood occurs roughly from $13 \mathrm{~ms}$ to $14 \mathrm{~ms}$. In the simulation, while a peak acceleration in z-direction is seen at nearly $14 \mathrm{~ms}$, the head encounters a negative $\mathrm{x}$ component acceleration at around $14 \mathrm{~ms}$, and then it experiences a positive $\mathrm{x}$ acceleration. The accelerations in the physical test see the same pattern as those in the simulation but with higher peak intensity. This difference likely results from the discrepancy in the material properties of the car hood, wind shield, or even dummy head between the real model and the FE model. Another reason might be due to contact stiffness chosen during the simulation. The paper's simulation in Elmasoudi $(2015)^{9}$ seem quite fluctuating, and have the peak accelerations larger than the experiment ones.

It is always good to verify the energy balance. In LSDYNA, the energy balance can be checked using the energy ratio, which is the ratio between total energy and the sum of initial energy and external work. The total energy includes kinetic energy, internal energy, frictional energy, rigid wall energy, damping energy, and hourglass energy, whereas initial energy is composed of initial kinetic energy and initial internal energy. The energy balance should hold at all times during the analysis, or alternatively the energy ratio should remain as close as possible to one. As can be seen from Figure 6, the energy ratio in the simulation satisfies energy balance as it is nearly close to one with a small variation.

\section{The V-dummy verification}

A comparison of HIC between the Hybrid III $50^{\text {th }}$ dummy and the V-dummy for various cases will be made. Car model used for these simulations is C5000 Pickup. The magnitudes of velocity of the car are 40 , 50 , and $60 \mathrm{~km} / \mathrm{h}$, and three angles of impact is 0,45 , and 90, which are shown in Figure 7. Boundary conditions is the same as those in the verification of the 

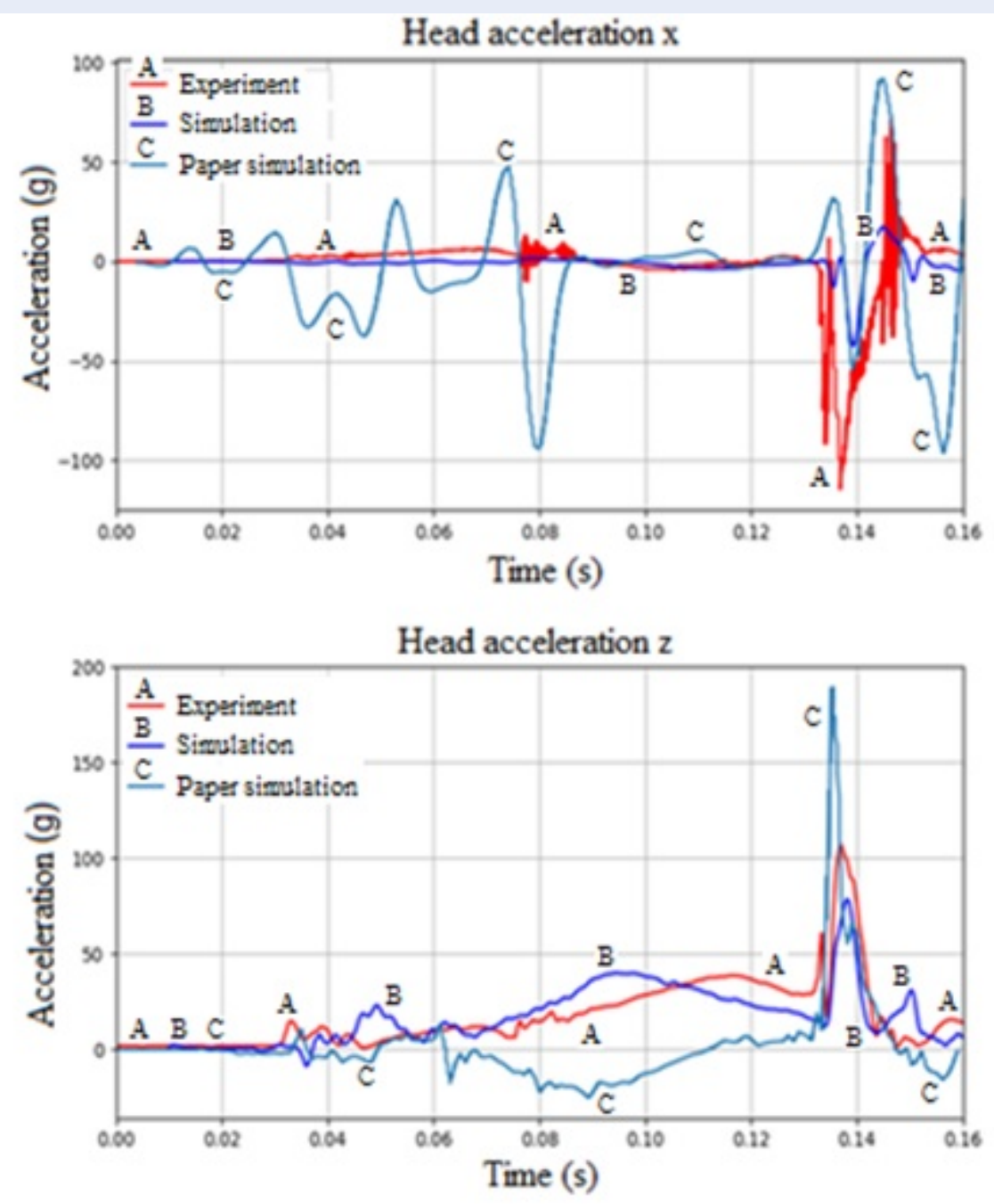

Figure 5: Head acceleration in g's.

Hybrid III $50^{t h}$. Note that HIC in this verification is caused by the first impact between the dummy and the car.

As illustrated in Table 3, HIC for the Hybrid III $50^{\text {th }}$ dummy in most cases is smaller than that for the $\mathrm{V}$ dummy with the exception of the case of $40 \mathrm{~km} / \mathrm{h}-$ angle 0 where the trend is reversed. In general, the simulation results show the same pattern as Eq. (4) does; that is HIC is inversely proportional to dummy size.

Here, a typical example is chosen to show the energy ratio and mass scaling during the simulation are described in Figure 8 and Figure 8 in the case of $50 \mathrm{~km} / \mathrm{h}$ - angle $0^{\circ}$ respectively. It is proposed that the percentage of mass increase should be less than $1 \%$ of physical mass, and energy ratio close to 1 . As seen from the figures, these criteria are well fulfilled. Note that the mass increase stems from mass scaling that is a technique in which nonphysical mass is added to a structure to obtain a larger time step size.

Status of impact of the dummy with the Pickup is shown in Figure 10. It indicates that when colliding with the Pickup, the dummy's head comes into contact with the hood.

\section{SIMULATION RESULTS AND DISCUSSION}

Vehicle modal is chosen in this research is SUV-2002 Ford Explorer ${ }^{10}$. The impact position and landing posture of pedestrian V-dummy when directly hit by SUV are illustrated in Table. 4. When striking by a car, the head of human body is hit on car bonnet which is name car-impact at first and finally impact 


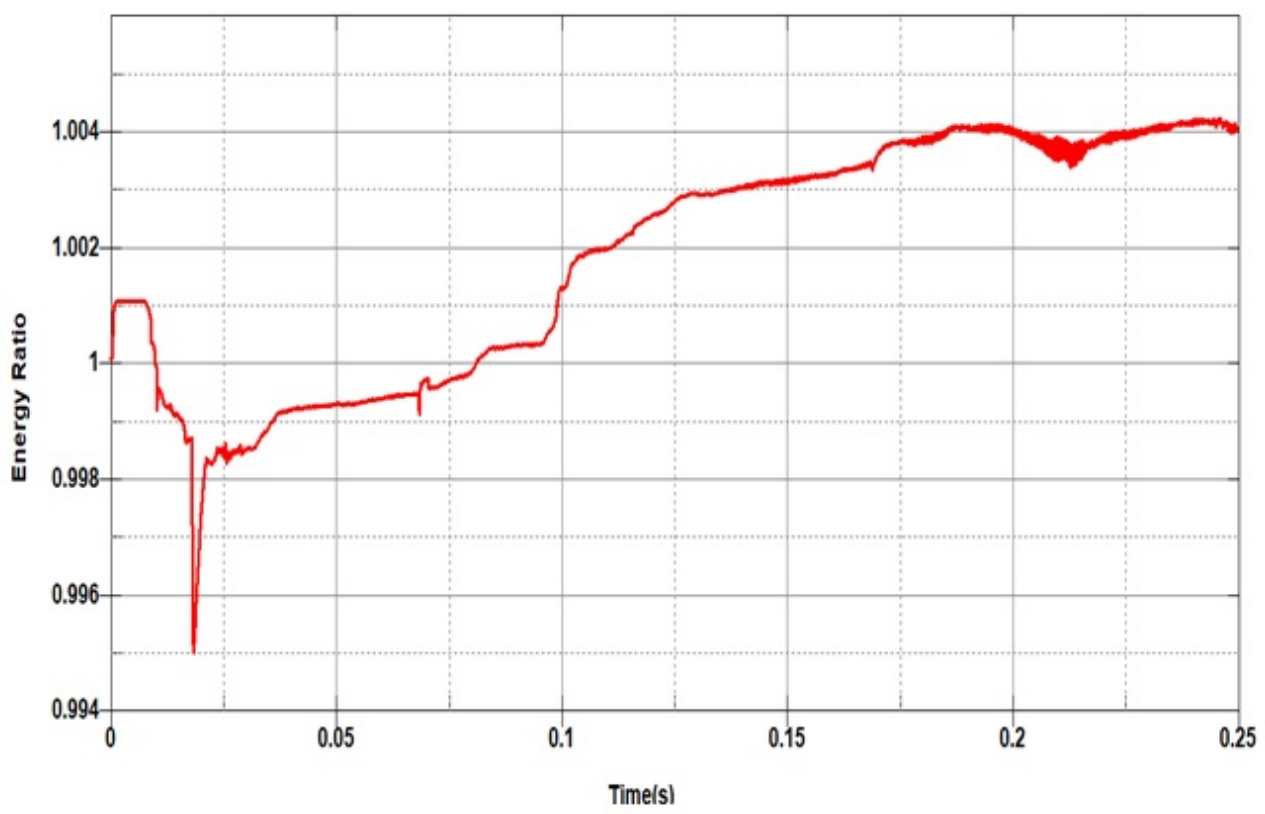

Figure 6: Energy ratio during the simulation.

Table 3: Comparisons of HIC for various cases

$\begin{array}{lll}\text { HIC for Pickup- pedestrian crashes } & & \\ \text { Case } & \text { The Hybrid III 50th } & \text { The V-dummy } \\ 40 \mathrm{~km} / \mathrm{h} \text { - angle } 0^{\circ} & 735 & 601 \\ 40 \mathrm{~km} / \mathrm{h} \text { - angle } 45^{\circ} & 585 & 654 \\ 40 \mathrm{~km} / \mathrm{h} \text { - angle } 90^{\circ} & 88 & 91 \\ 50 \mathrm{~km} / \mathrm{h} \text { - angle } 0^{\circ} & 679 & 750 \\ 50 \mathrm{~km} / \mathrm{h} \text { - angle } 45^{\circ} & 1256 & 1483 \\ 50 \mathrm{~km} / \mathrm{h} \text { - angle } 90^{\circ} & 241 & 704 \\ 60 \mathrm{~km} / \mathrm{h} \text { - angle } 0^{\circ} & 1283 & 1602 \\ 60 \mathrm{~km} / \mathrm{h} \text { - angle } 45^{\circ} & 1864 & 2353 \\ 60 \mathrm{~km} / \mathrm{h} \text { - angle } 90^{\circ} & 325 & 770\end{array}$

to ground which is name ground-impact. These two phases of impact are demonstrated from Figure 11 to Figure 16.

SUV, which also known as high ground clearance vehicles, at the case of side-on impact $90^{\circ}$, the HIC at $40 \mathrm{~km} / \mathrm{s}$ is much lower than any other cases. This can be reasoned that in the simulation, according to the key frames from Figure 12 to Figure 16, it shows that dummy's head did not hit perpendicularly to car bonnet in the car-impact phase but make a small sliding on it, which leads to a significant drop in con- tact force. Consequently, resultant head acceleration drops considerably, and so does HIC. It should be, furthermore, noted that simulations for a crash at an angle of $90^{\circ}$ and velocity of $40 \mathrm{~km} / \mathrm{h}$ were repeated numerous times to prove there are no computational errors, and in all run cases, the same results are also achieved. From these results, it is expected that pedestrians might suffer severe spinal cord injuries rather than head injuries because in most of cases, SUV mainly hits pedestrians' body. 

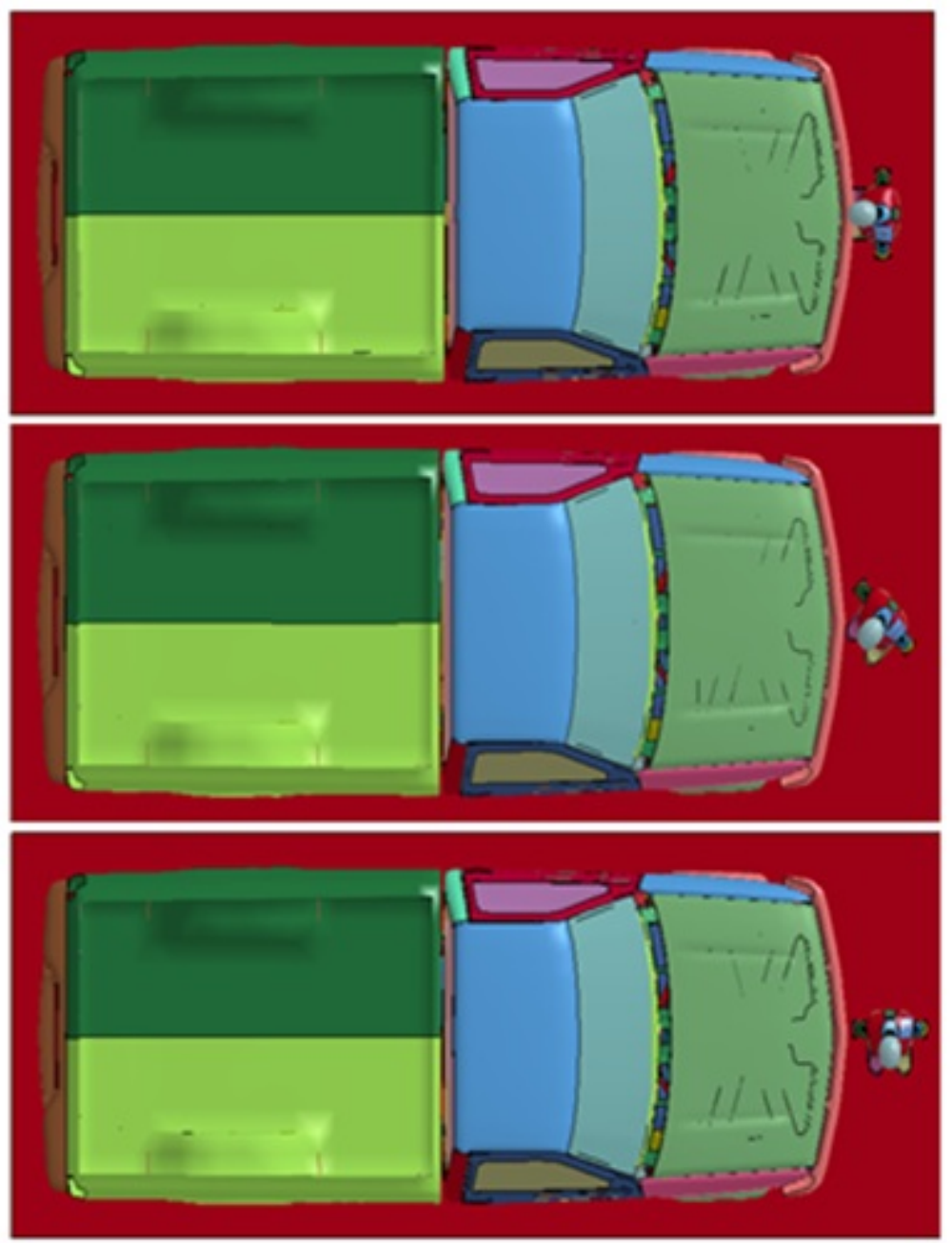

Figure 7: Dummy positioning at angle of $0^{\circ}, 45^{\circ}$, and $90^{\circ}$ (top to bottom).

In the first phase of contact, car-impact, the trend of HIC is increased linearly for both factors - impact angle and initial velocity as described in Table 4 and drawn graphically in Figure 17. During the carimpact, the peak value of HIC is around 1200 (being directly hit - as impact angle equals $0^{\circ}$, by high ground clearance vehicle), which may cause the skull fracture, but without severe neurological damages; no damages of spiral cord - according to the AIS table Table. 2 .

Moreover, as demonstrated in Figure 17, there is an increase in HIC when the speed rises from $20 \mathrm{~km} / \mathrm{h}$ to $60 \mathrm{~km} / \mathrm{h}$. At the impact direction at $45^{\circ}$ and $90^{\circ}$, the HIC is below 1000, which corresponds to AIS below 3. Of three angles, $0^{\circ}$ degree is the most dangerous, and it is followed by $45^{\circ}$ and $90^{\circ}$ degrees respectively. In conclusion, if car velocity is below $40 \mathrm{~km} / \mathrm{h}$, victims just suffer from less-than-15-minute unconsciousness without involving any skull fracture, whereas if velocity is larger than $40 \mathrm{~km} / \mathrm{h}$, pedestrians will encounter more-than-15-minute unconsciousness.

For ground impact, pedestrian-to-ground collision, all of the head injury criterion exceeds the threshold of human tolerance except speed of $20 \mathrm{~km} / \mathrm{h}$. HIC is described in Table 5 and drawn graphically in Figure 18. It should be pointed out that since the ground is considered as an absolutely rigid body, contact forces it applies on the dummy is far larger than in the first impact. As a result, HIC in ground impact is very large, and it suggests that ground impact is the key cause of severe head injuries or even death. 

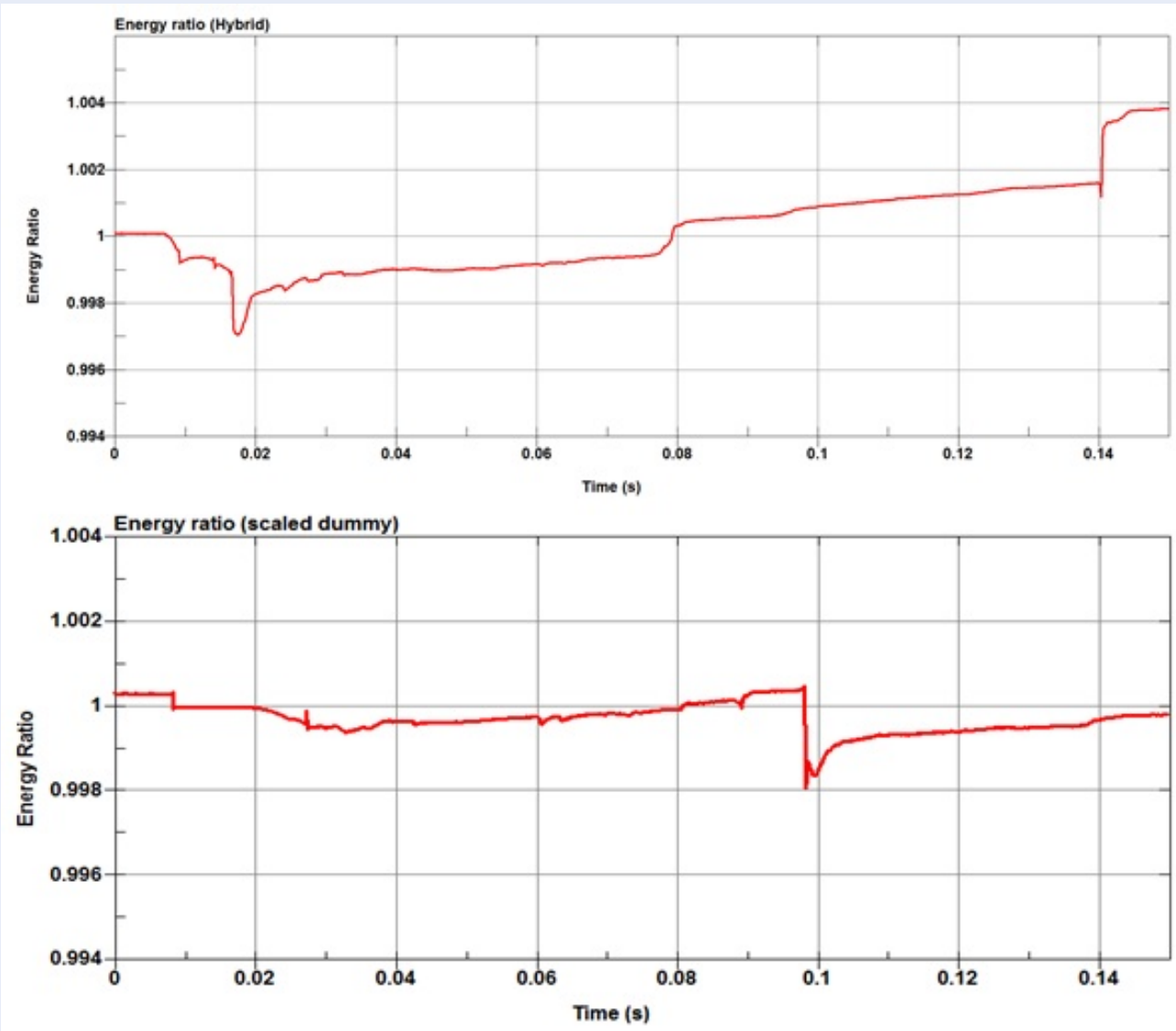

Figure 8: Energy ratio for the case of $50 \mathrm{~km} / \mathrm{h}$ - angle $0^{\circ}$.

Table 4: HIC (AIS) in case of car-impact

\begin{tabular}{llll} 
Impact angle (degree) & $0^{\circ}$ & $45^{\circ}$ & $90^{\circ}$ \\
Speed $(\mathrm{km} / \mathrm{h})$ & & & \\
20 & 33 (AIS 0) & 113 (AIS 0) & 34 (AIS 0) \\
30 & 158 (AIS 1) & 102 (AIS 0) & 50 (AIS 0) \\
40 & 256 (AIS 1) & 206 (AIS 1) & 86 (AIS 0) \\
50 & 773 (AIS 2) & 649 (AIS 2) & 191 (AIS 1) \\
60 & 1198 (AIS 3) & 960 (AIS 3) & 798 (AIS 2) \\
\hline
\end{tabular}

Table 5: HIC (AIS) in case of ground-impact.

\begin{tabular}{llll}
\hline $\begin{array}{l}\text { Impact angle (degree) } \\
\text { Speed }(\mathrm{km} / \mathrm{h})\end{array}$ & $0 \mathrm{o}$ & 450 & $90 \mathrm{o}$ \\
20 & & & \\
30 & 1053 (AIS 3) & 357 (AIS 1) & 914 (AIS 3) \\
40 & 11600 (AIS 3) & 8678 (AIS 6) & 5830 (AIS 6) \\
50 & 11830 (AIS 6) & 5775 (AIS 6) & 11060 (AIS 6) \\
60 & 10640 (AIS 6) & 12080 (AIS 6) & 8773 (AIS 6) \\
\hline
\end{tabular}



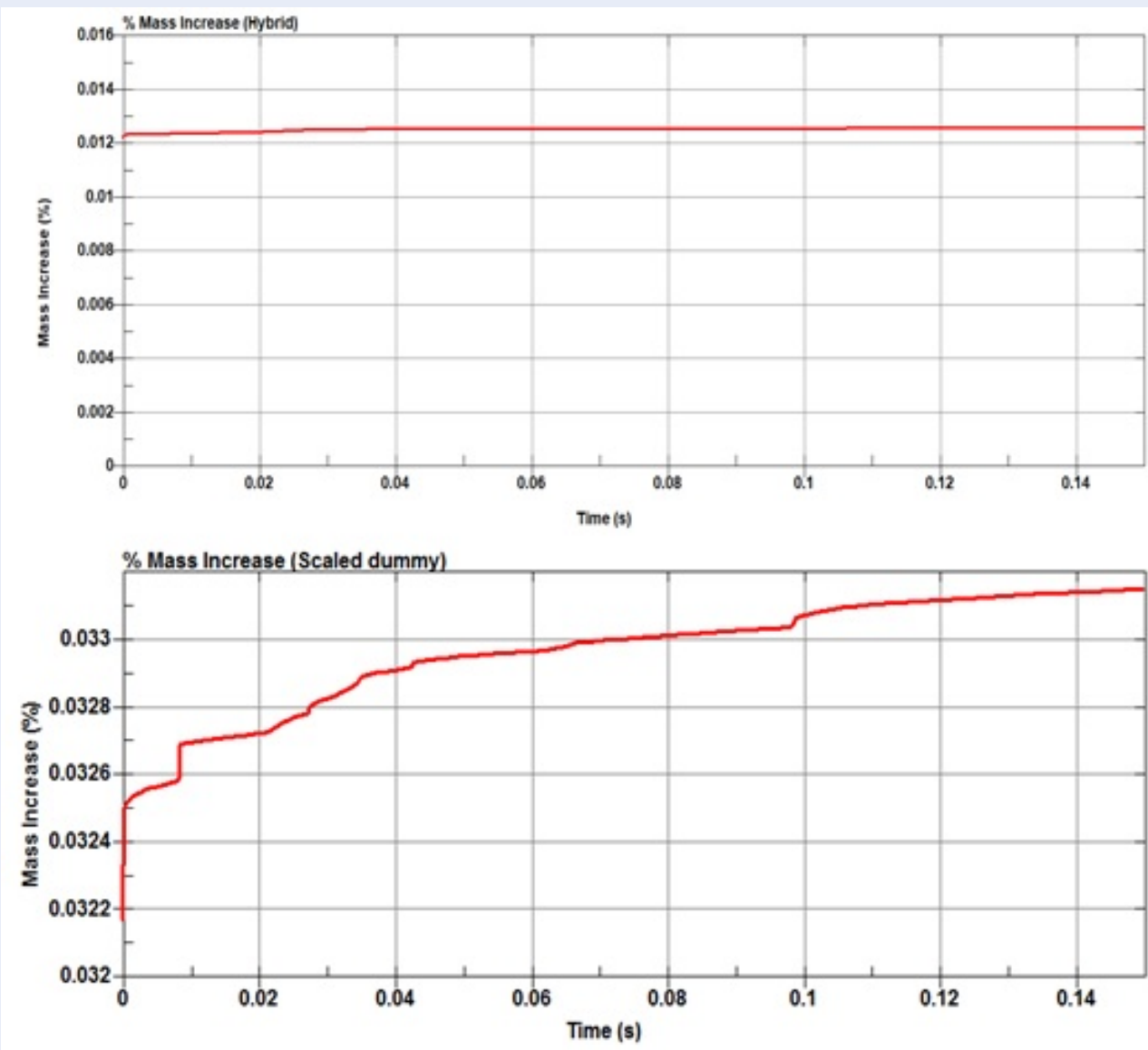

Figure 9: Percentage of mass increase for the case of $50 \mathrm{~km} / \mathrm{h}$ - angle $0^{\circ}$.

\section{CONCLUSION}

In this study, a series of simulation is conducted to verify the Hybrid III $50^{\text {th }}$ with a comparison with experimental data, and qualitatively assess how well the results of scaled dummy simulations match with the anticipated trend. A set of fifteen crash simulations between SUV and V-dummy is performed, and the findings show that in the first impact, pedestrians are likely to suffer spinal injuries, whereas in the ground impact, head injuries are the principal cause of death. When pedestrian is hit by SUV at angle $90^{\circ}$, shoulder strike on car bonnet before head, it causes HIC in impact angle $90^{\circ}$ is lower than the two others. $\mathrm{HIC}$ in case of pedestrian-to-ground collision exceeds the threshold of human tolerance except speed of 20 $\mathrm{km} / \mathrm{h}$. It cannot be recognized the correlation between HIC and impact speed in the phase of groundimpact.

\section{ACKNOWLEDGMENT}

This research is funded by Vietnam National University Ho Chi Minh City (VNU-HCM) under grant number C2019-20-04.

Numerical simulation in this paper is conducted in High Performance Computing Laboratory (HPC Lab), Faculty of Computer Science \& Engineering, Ho Chi Minh City University of Technology - HCMUT, Vietnam National University Ho Chi Minh City (VNU-HCM).

\section{LIST OF ABBREVIATIONS}

FEM: Finite Element Method.

HIC: Head Injury Criterion

AIS: Abbreviated Injury Scale

V-dummy: Vietnamese dummy

NHTSA: National Highway Traffic Safety Administration 


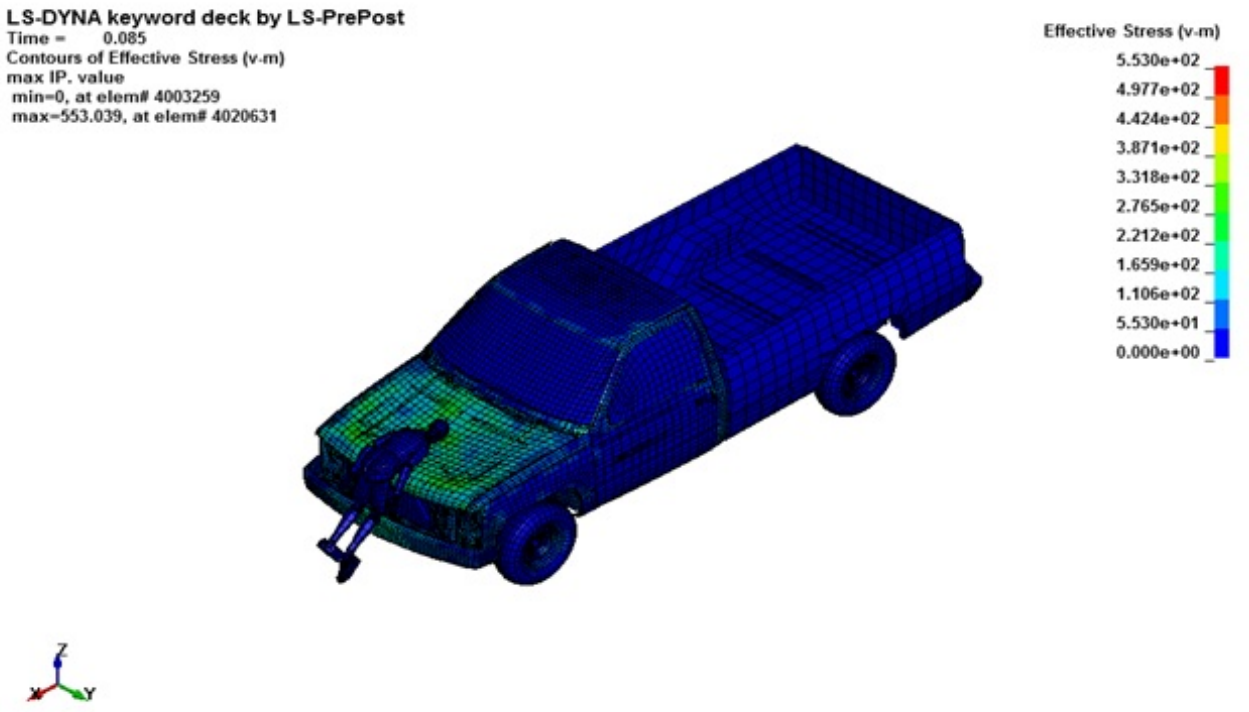

Figure 10: Impact position

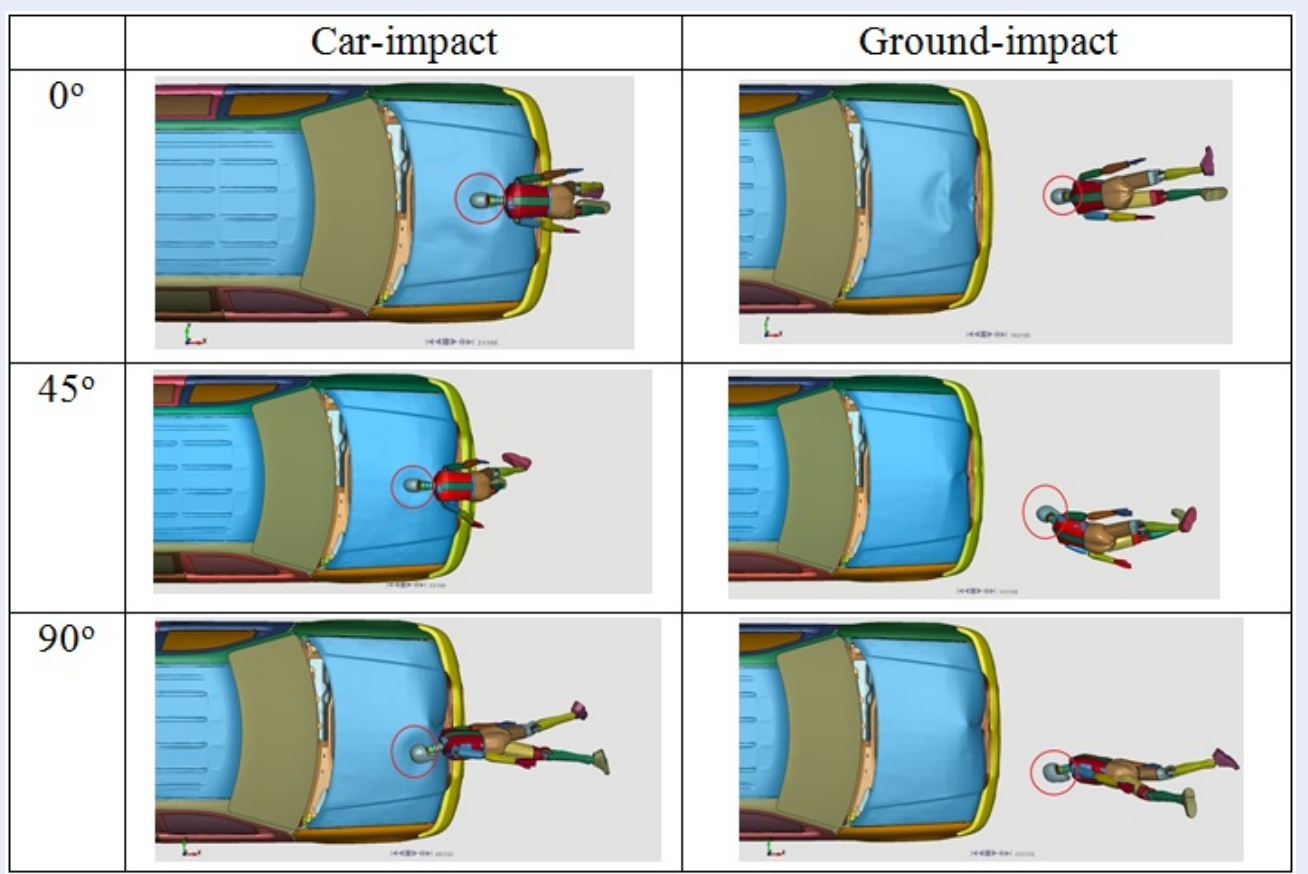

Figure 11: Impact position and landing posture of pedestrian in case of SUV 


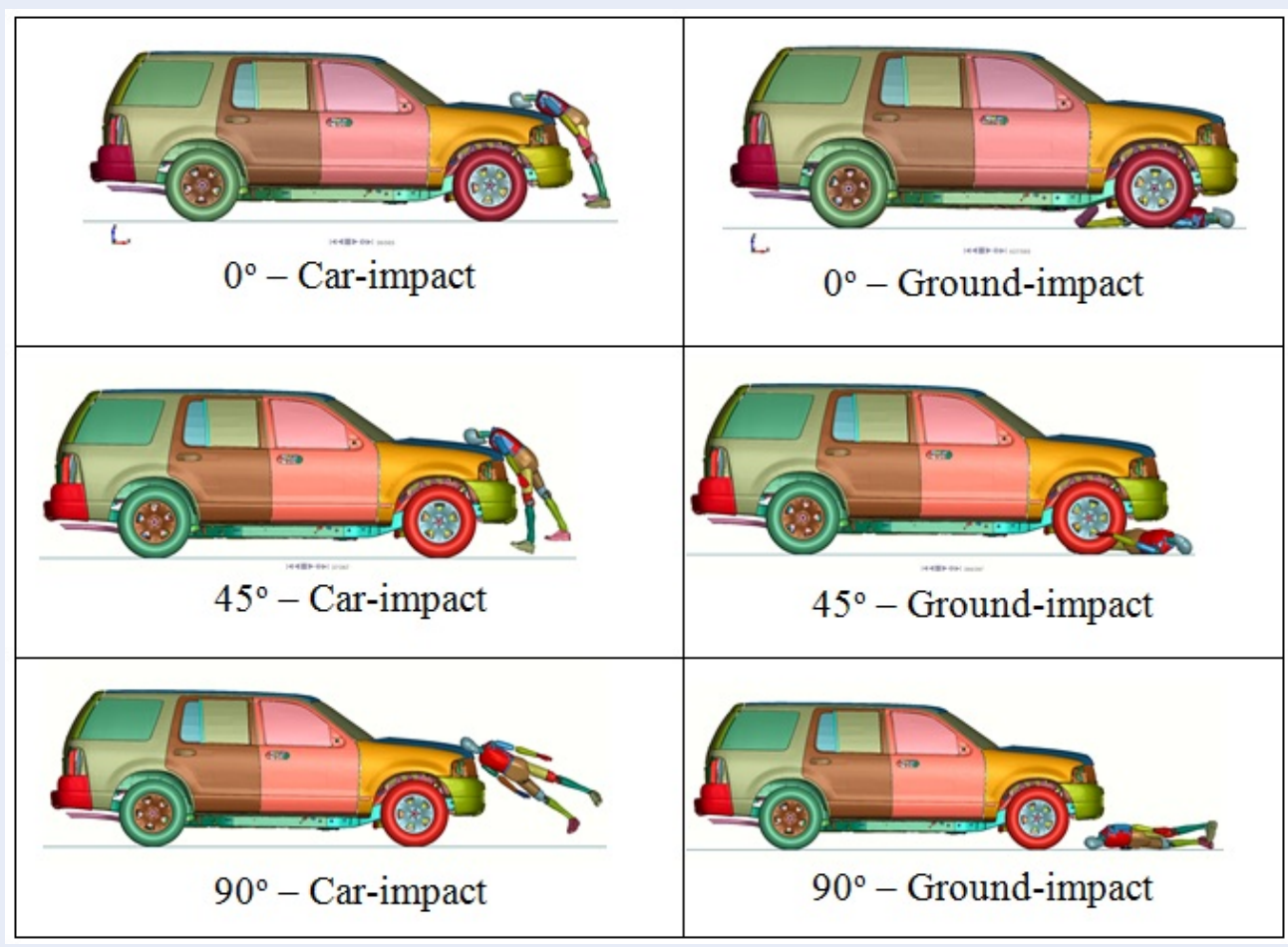

Figure 12: Key frames of SUV simulation at $20 \mathrm{~km} / \mathrm{h}$

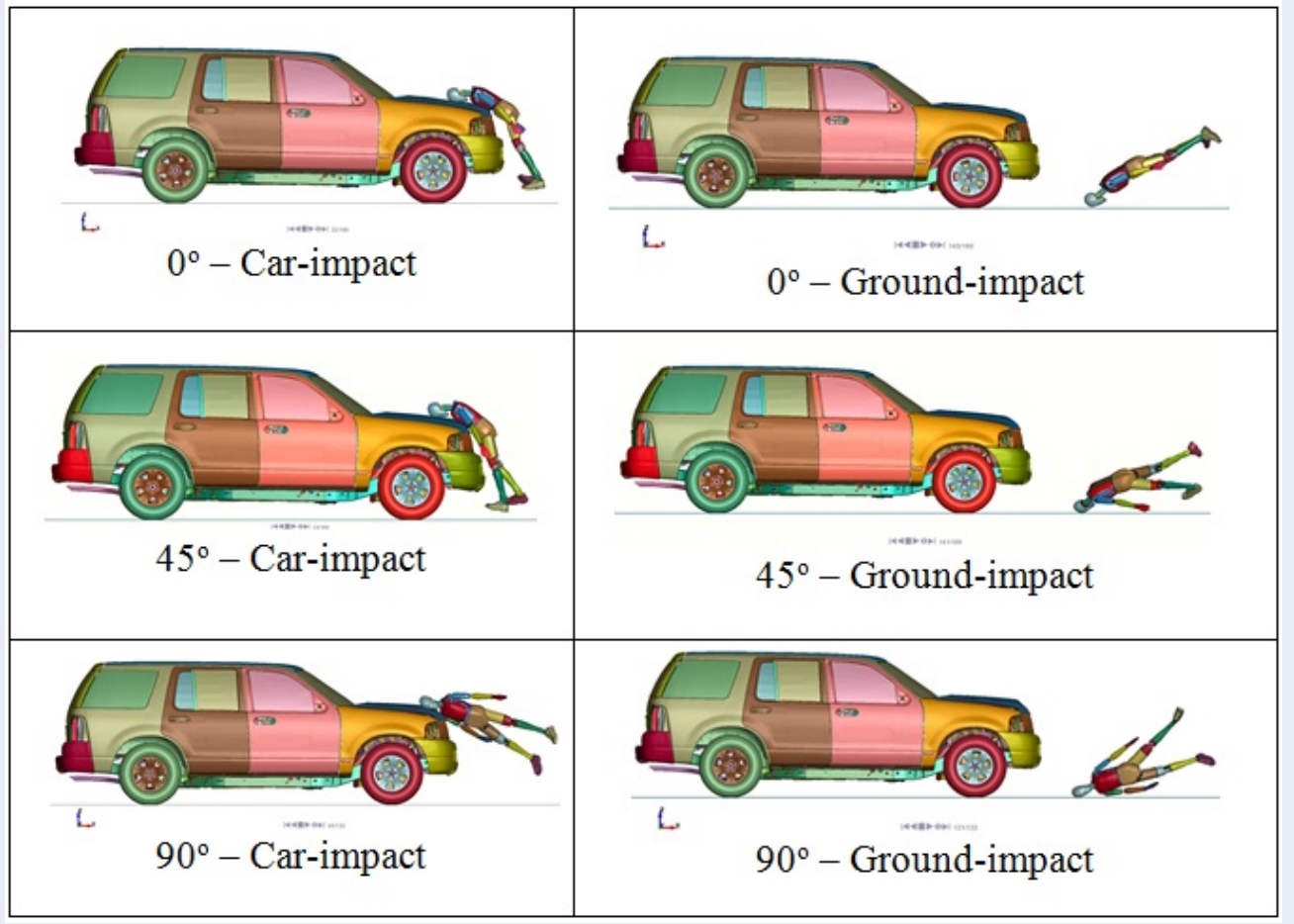

Figure 13: Key frames of SUV simulation at $30 \mathrm{~km} / \mathrm{h}$ 


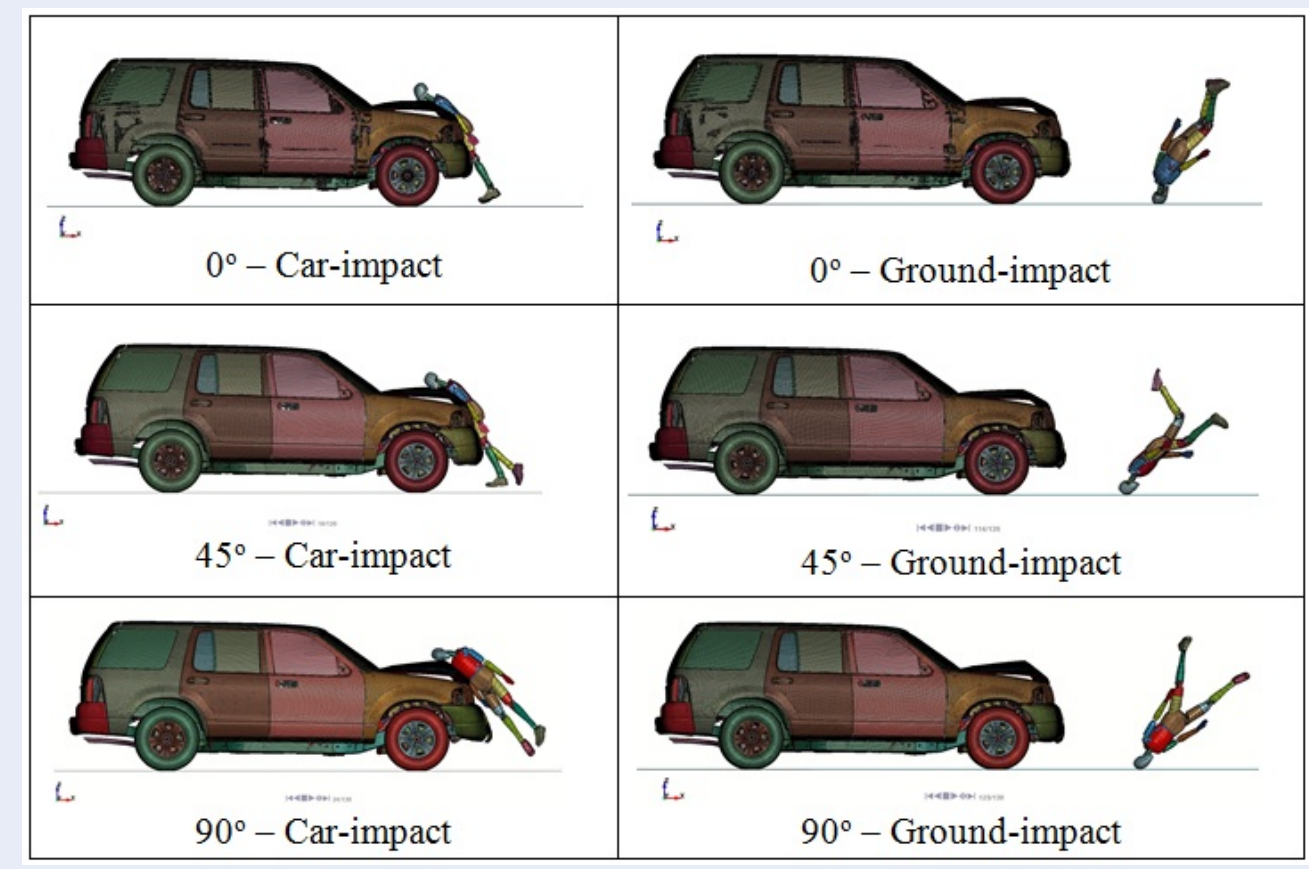

Figure 14: Key frames of SUV simulation at $40 \mathrm{~km} / \mathrm{h}$

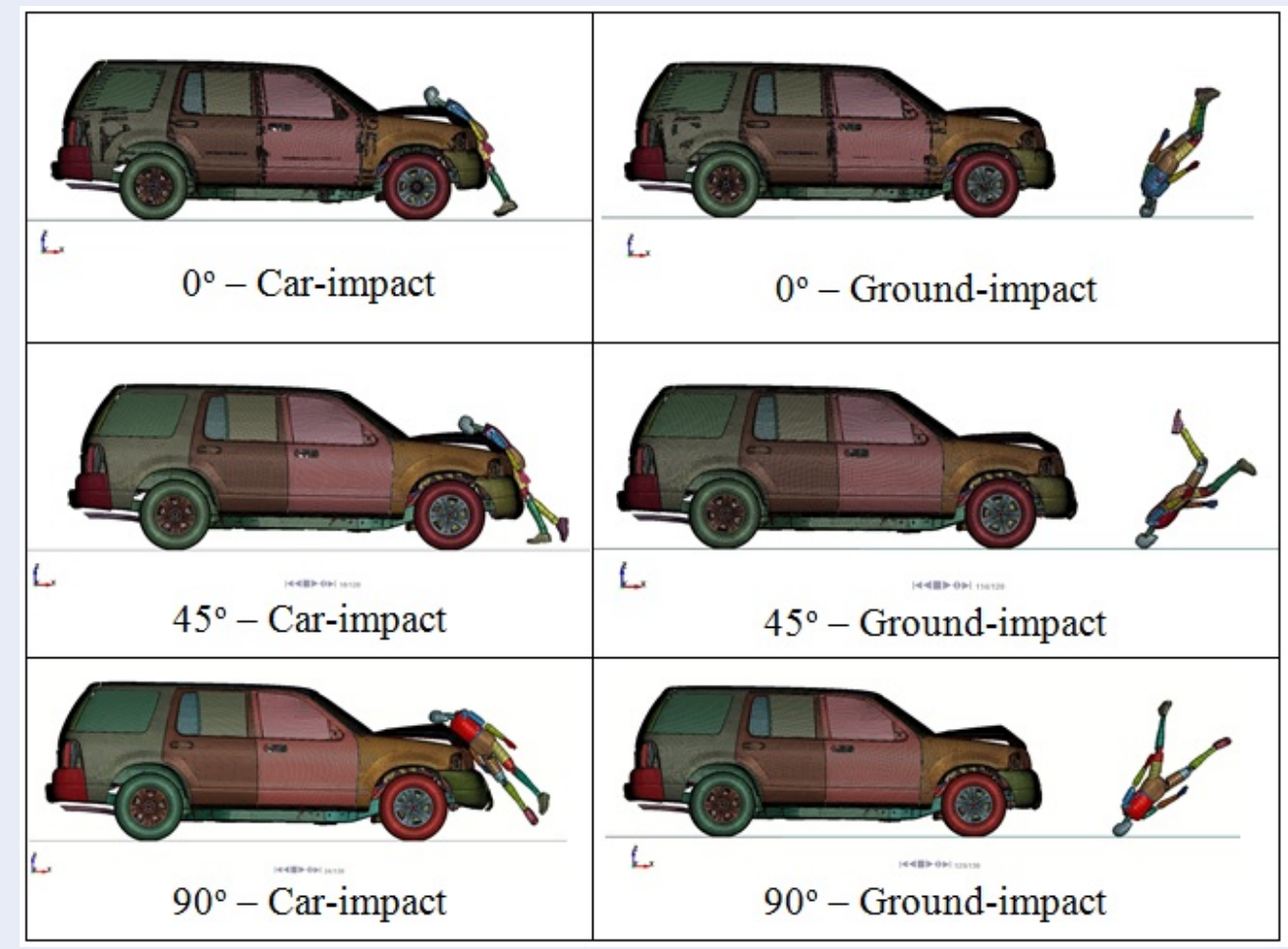

Figure 15: Key frames of SUV simulation at $50 \mathrm{~km} / \mathrm{h}$ 


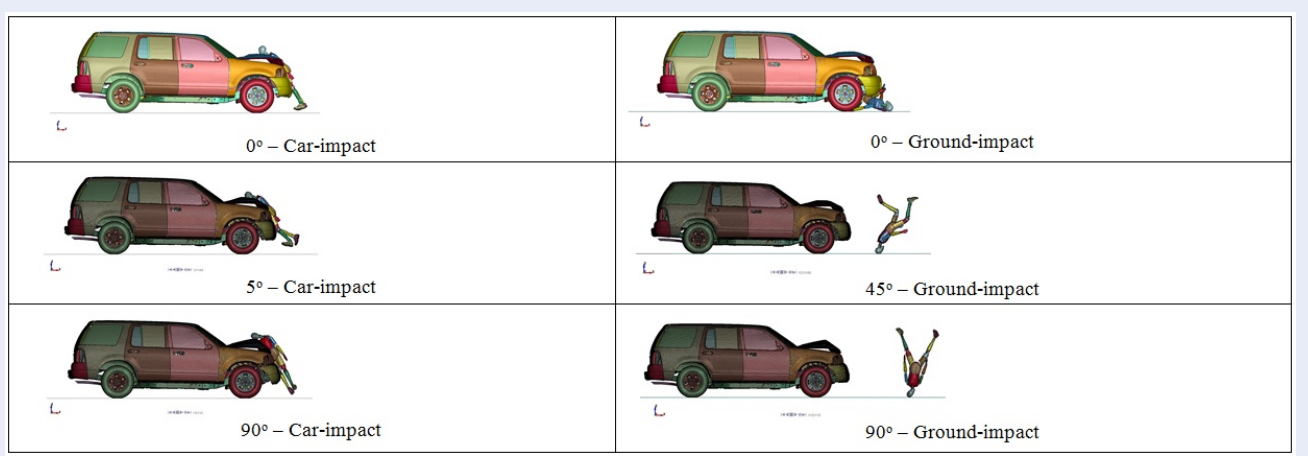

Figure 16: Key frames of SUV simulation at $60 \mathrm{~km} / \mathrm{h}$

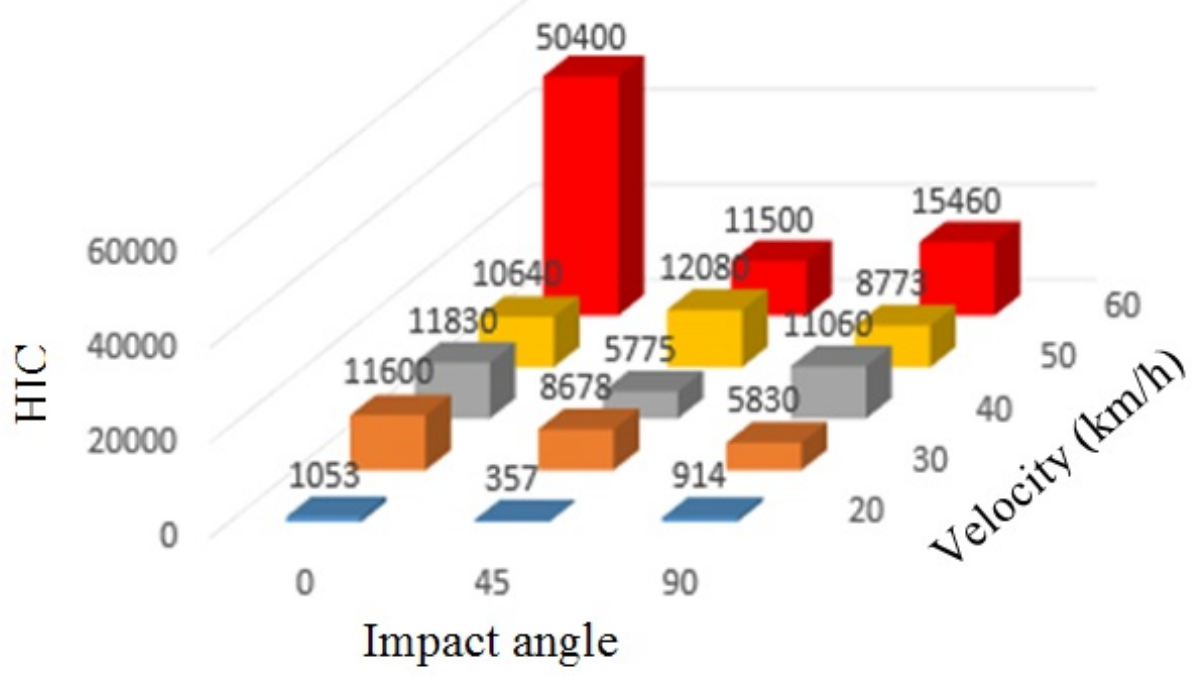

Figure 17: HIC during the car-impact

\section{COMPETING INTERESTS}

The authors pledge that there are no conflicts of interest in the publication of the paper.

\section{AUTHORS' CONTRIBUTION}

Hung Anh LY takes responsibility as principal investigator, brainstorming ideas for writing articles and reviewing articles; Orientation, evaluation and interpretation of simulation results.

Dinh Bao NGUYEN has participated in data analysis and evaluation results.

Anh Huy NGUYEN has participated in simplifying original FEM vehicle models and running crash simulation, supporting writing articles.

\section{REFERENCES}

1. World Health Organization: Violence and Injury Prevention [Online] [Accessed 2511 2018];Available from: https://www.who.int/violence_injury_prevention/road_traffic/ countrywork/vnm/en/.

2. Ly AH, Nguyen BD, Nguyen HA. Methodology for scaling finite element dummy and validation of a Hybrid III dummy model in crashworthiness simulation. Sci. Tech. Dev. J. - Engineering and Technology; 2(SI2, 2019):SI105-SI113;Available from: https://doi.org/10.32508/stdjet.v2iSI2.468.

3. Hyncik L. On scaling of human body models. University of West Bohemia. 2007;

4. Untaroiu CD. A study of the pedestrian impact kinematics using fnite element dummy: the corridors and dimensional analysis scaling of upper-body trajectories. International Journal of Crashworthiness. 2008:13:468-478. Available from: https://doi.org/10.1080/13588260802055387.

5. Hybrid III. [Online] [Accessed 2512 2018];Available from: https://en.wikipedia.org/wiki/Hybrid_III.

6. Quyên $H$. Sau 25 năm người Việt chỉ cao tăng 3 $\mathrm{cm}$ chiều cao. [Online] [Accessed 2511 2018];Available from: https://news.zing.vn/sau-25-nam-nguoi-viet-chi-tang3-cm-chieu-cao-post816342.html. 


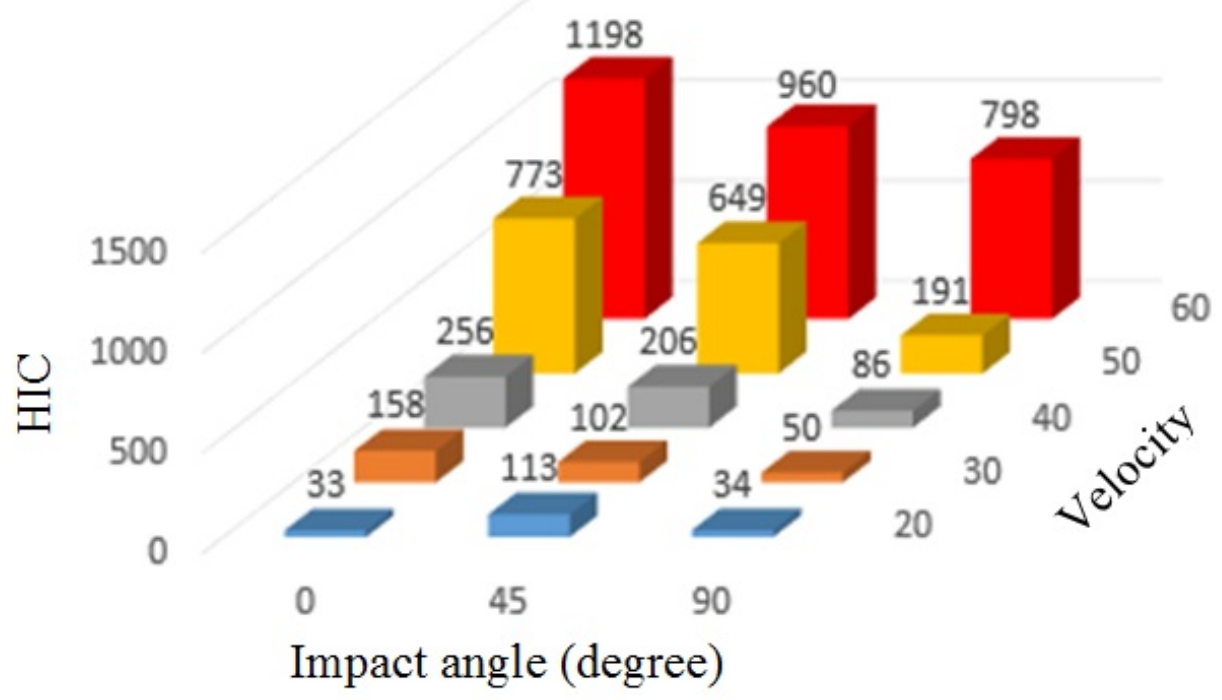

Figure 18: HIC during the ground-impact

7. Fredriksson R, Håland Y, Yang J. Evaluation of a New Pedestrian Head Injury Protection System with a Sensor in the Bumper and Lifting of the Bonnet's Rear Edge. Proceedings of the 17th International Technical Conference on the Enhanced Safety of Vehicles. 2001;

8. Mertz HJ, Irwin AL, Melvin JW, Stanaker RL, Beebe MS. Size, Weight and Biomechanical Impact Response Requirements for Adult Size Small Female and Large Male Dummies. SAE Technical Paper Series. 1989;p. 133-144. Available from: https: //doi.org/10.4271/890756.

9. Elmasoudi S. Finite element modelling of a pedestrian impact dummy. Master thesis. KTH Royal Institude of Technology, Sweden. 2015;.

10. Marzougui D, Samaha RR, Tahan F, Cui C, Kan CD. Extended 451 Validation of the Finite Element Model for the 2002 Ford Explorer Sport Utility Vehicle, National Crash Analysis Center. 2012;. 


\title{
Đánh giá chấn thương đầu của người đi bộ Việt Nam với xe SUV bằng phương pháp mô phỏng
}

\author{
Lý Hùng Anh ${ }^{1,2, *}$, Nguyễn Đình Bảo ${ }^{1,2}$, Nguyễn Anh Huy ${ }^{1,2}$
}

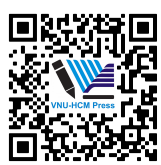

Use your smartphone to scan this QR code and download this article

\begin{abstract}
TÓM TÁ́T
Mô phỏng thử nghiệm va chạm sử dụng phương pháp phần tử hữu hạn ngày càng phổ biến trong ngành công nghiệp ô tô vi tính khả thi và tiết kiệm chi phí. Phần lớn các mô hình phần tử hữu hạn của hình nhân (dummy) được sử dụng trong mô phỏng va chạm được xây dựng dựa trên dữ liệu nhân trắc học và cơ sinh học của người Mỹ và Châu Âu. Vi vậy, cần phải phát triển một thuật toán chia tỷ lệ để điều chỉnh kích thước dummy chuẩn thành một kích thước mong muốn mà không cần xây dựng lại toàn bộ mô hình. Trong bài báo này, phương pháp thu nhỏ mô hình để có V-dummy được tóm tắt ngắn gọn. V-dummy được thu nhỏ từ mô hình dummy Hybrid III do LS-DYNA cung cấp để phù hợp với nhân trắc học của người Việt Nam. Nguy cơ chấn thương đầu của người đi bộ khi va chạm trực diện với một chiếc SUV được nghiên cứu. Tổng cộng mười lăm mô phỏng đã được thực hiện để nghiên cứu chấn thương đầu thông qua HIC (Tiêu chuẩn chấn thương đầu). Khi bị ô tô tông, đầu sẽ đập vào nắp ca-pô ô tô trước và bay trong không trung sau đó trước khi va chạm xuống đất. Vị trí của đầu va đập vào ô tô phụ thuộc lớn vào góc va chạm, nhưng tư thế tiếp đất của người đi bộ không có mối liên hệ với tốc độ hoặc góc va chạm. Trong giai đoạn va chạm với ô tô, người đi bộ chịu mức độ chấn thương đâu thấp, tuy nhiên khi đập đầu xuống đất, HIC thường vượt quá ngưỡng chịu đựng của con người ngoại trừ tốc độ $20 \mathrm{~km} / \mathrm{h}$. Khi người đi bộ bị xe SUV đâm ở góc $90^{\circ}$, vai va vào nắp ca-pô của ô tô trước đầu, gây ra HIC hấp hơn khi va chạm ơ góc $0^{\circ}$ và $45^{\circ}$. Mối tương quan giữa tốc độ va chạm và HIC trong giai đoạn đập đầu xuống đất chưa được xác định rõ trong nghiên cứu này.

Từ khoá: An toàn trong va chạm, tử vong của người đi bộ, dummy, HIC, gia tốc
\end{abstract}

${ }^{1}$ Khoa Kỹ thuật Giao thông, Trường Đại học Bách khoa, Việt Nam

${ }^{2}$ Đại học Quốc gia Thành phố Hồ Chí Minh, Việt Nam

Liên hệ

Lý Hùng Anh, Khoa Kỹ thuật Giao thông, Trường Đại học Bách khoa, Việt Nam

Đại học Quốc gia Thành phố Hồ Chí Minh, Việt Nam

Email: lyhunganh@hcmut.edu.vn

Lịch sử

- Ngày nhận: 16-8-2019

- Ngày chấp nhận: 25-3-2021

- Ngày đăng: 09-4-2021

DOI : 10.32508/stdjet.v3iSI2.555

\section{Check for updates}

\section{Bản quyền}

๑) ĐHQG Tp.HCM. Đây là bài báo công bố mở được phát hành theo các điều khoản của the Creative Commons Attribution 4.0

International license.

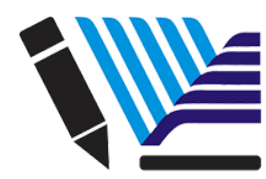

VNU-HCM Press
Trích dẫn bài báo này: Anh L H Bảo ND, Huy NA Đánh giá chấn thương đầu của người đi bộ Việt Nam với xe SUV bằng phương pháp mô phỏng. Sci. Tech. Dev. J. - Eng. Tech.; 3(SI2):SI129-SI144. 